\title{
Phlebotomines in an area endemic for American cutaneous leishmaniasis in northeastern coast of Brazil
}

\author{
Flebotomíneos em uma área endêmica para Leishmaniose Tegumentar Americana no litoral do \\ Nordeste do Brasil
}

\begin{abstract}
Ana Patricia Oliveira da Silva ${ }^{1,2}$; Débora Elienai de Oliveira Miranda ${ }^{3}$; Marcos Antônio Bezerra Santos ${ }^{4}$; Neurisvan Ramos Guerra ${ }^{5}$; Silvia Rafaelli Marques' ; Leucio Câmara Alves ${ }^{5}$; Rafael Antonio Nascimento Ramos ; Gílcia Aparecida de Carvalho ${ }^{4 *}$
\end{abstract}

${ }^{1}$ Programa de Ciência Animal Tropical, Universidade Federal Rural de Pernambuco - UFRPE, Recife, PE, Brasil

${ }^{2}$ Departamento Municipal de Saúde, Secretaria de Saúde de Igarassu, Prefeitura Municipal de Igarassu, Igarassu, PE, Brasil

${ }^{3}$ Centro de Pesquisas Aggeu Magalhães, Fundação Oswaldo Cruz - FIOCRUZ, Recife, PE, Brasil

${ }^{4}$ Unidade Acadêmica de Garanhuns, Universidade Federal Rural de Pernambuco - UFRPE, Garanhuns, PE, Brasil

${ }^{5}$ Departamento de Medicina Veterinária, Universidade Federal Rural de Pernambuco - UFRPE, Recife, PE, Brasil

Received January 7, 2017

Accepted June 6, 2017

\begin{abstract}
Phlebotomines have worldwide distribution with many species present in Brazil, including the northeastern region, where the fauna is very diverse. The aim of this study was to identify the sandfly fauna in an area endemic for American cutaneous leishmaniasis (ACL) in the state of Pernambuco. Sandflies were caught on three consecutive nights every month from October 2015 to September 2016, from 5 pm to 5 am, using seven light traps of Centers for Disease Control (CDC) type. Females were identified and used for molecular Leishmania detection. A total of 2,174 specimens belonging to ten species were collected: Lutzomyia choti $(88.2 \% ; 1,917 / 2,174)$ was the most abundant species, followed by Lutzomyia whitmani $(8.1 \% ; 176 / 2,174)$ and Lutzomyia sordellii $(1.5 \% ; 33 / 2,174)$. The majority of the specimens were collected in peridomestic areas $(64.1 \% ; 1,394 / 2,174)$ and during the rainy period. All the samples examined were negative for Leishmania spp. The presence of Lutzomyia whitmani indoors and in peridomestic areas indicates that the inhabitants of this area are exposed to the risk of infection by the parasites responsible for ACL.
\end{abstract}

Keywords: Lutzomyia, Leishmania, vectors.

\section{Resumo}

Os flebotomíneos apresentam uma ampla distribuição mundial com muitas espécies presentes no Brasil, inclusive na regiāo Nordeste, onde a fauna é bastante rica. O objetivo desse estudo foi identificar a fauna de flebotomíneos em uma área endêmica para Leishmaniose Tegumentar Americana (LTA), no estado de Pernambuco. As capturas foram realizadas mensalmente, durante três noites consecutivas das $17 \mathrm{~h}$ às $5 \mathrm{~h}$, utilizando sete armadilhas luminosas tipo CDC, no período de outubro de 2015 a setembro de 2016. As fêmeas identificadas foram utilizadas para análise molecular para detecção de Leishmania. Um total de 2.174 espécimes pertencentes a dez espécies foram coletadas: Lutzomyia choti $(88,2 \% ; 1.917 / 2.174)$ a espécie mais abundante, seguida por Lutzomyia whitmani $(8,1 \% ; 176 / 2.174)$ e Lutzomyia sordellii $(1,5 \% ; 33 / 2.174)$. A maioria dos espécimes foi coletada no peridomicílio $(64,1 \% ; 1.394 / 2.174)$ e no período chuvoso. Todas as amostras avaliadas foram negativas para Leishmania spp. A presença de Lutzomyia whitmani no intradomicílio e peridomicílio indica que a população residente nesta área está exposta ao risco de infecção por parasitos causadores de LTA.

Palavras-chave: Lutzomyia, Leishmania, vetores.

*Corresponding author: Gílcia Aparecida de Carvalho. Unidade Acadêmica de Garanhuns, Universidade Federal Rural de Pernambuco - UFRPE,

Av. Bom Pastor, s/n, Bairro Boa Vista, CEP 55292-270, Garanhuns, PE, Brasil.

e-mail: gilciasilva@yahoo.com.br 


\section{Introduction}

Phlebotomines (Diptera: Psychodidae: Phlebotominae) are insects of great public health importance, given that they are responsible for transmission of viruses, bacteria and parasites, which include protozoa belonging to the genus Leishmania (Kinetoplastida: Trypanosomatidae). Indeed, it is believed that 98 phlebotomines species are proven or suspected vectors of human leishmaniasis (MAROLI et al., 2013).

These dipterans are distributed around the world, with major abundance in Neotropical regions (SHIMABUKURO \& GALATI, 2011). Among the most important species, the ones belonging to the genus Lutzomyia (sensu YOUNG \& DUNCAN, 1994) are responsible for transmission of leishmaniasis in the New World (KILLICK-KENDRICK, 1999). The geographical spread of American cutaneous leishmaniasis (ACL) has been directly correlated with the distribution of sandfly species. This is influenced by environmental and climatic changes due to human activity, thus resulting in adaptation of wild species to modified environments, such as inside domestic animal shelters and in areas surrounding them (KOVATS et al., 2001; PATZ et al., 2004; COSTA et al., 2007).

In Brazil, several species are involved in transmission of ACL: Lutzomyia whitmani, Lutzomyia intermedia, Lutzomyia wellcomei, Lutzomyia complexa, Lutzomyia neivai, Lutzomyia fischeri and Lutzomyia migonei (MAROLI et al., 2013). Particularly in the northeastern region, the fauna is very diverse. For instance, in the state of Pernambuco, the diversity of species is lower than in the states of Maranhão and Bahia, but it is much greater than in the states of Alagoas, Ceará, Paraíba, Piauí, Rio Grande do Norte and Sergipe (DANTAS-TORRES et al., 2010). Studies conducted in the state of Pernambuco have identified species of Lutzomyia transmitters of ACL (LUCENA et al., 1984; BRANDÁO-FILHO et al., 1998; SILVA \& VASCONCELOS, 2005; BALBINO et al., 2005; ANDRADE et al., 2005; DANTASTORRES et al., 2010; GUIMARÁES et al., 2012; MIRANDA et al., 2015; AGRA et al., 2016).

In Pernambuco, ACL occurs in all regions of the state (ANDRADE et al., 2005), and some areas are endemic for ACL, such as the Três Ladeiras district of the municipality of Igarassu. In this area, 62 cases of human ACL were reported between 2008 and 2013 (RAMOS, 2015). Nevertheless, knowledge of the phlebotomine fauna in some endemic areas is still limited, which makes it difficult to control these vectors. Therefore, the present study aimed to contribute knowledge of the phlebotomine fauna in an area endemic for ACL in northeastern coast of Brazil.

\section{Materials and methods}

\section{Study area}

This study was conducted in the district of Três Ladeiras, which is endemic for ACL. It is located in the municipality of Igarassu (7050'00" S and 34054'30" W), in the metropolitan region of Recife, Pernambuco, Brazil. The district of Três Ladeiras has a total area of $102.3 \mathrm{Km}^{2}$ which represents $33.44 \%$ of the total area of the municipality of Igarassu (2000). The study area was located in the rural zone, where the main economic activity consists of sugar cane crops. In addition, it has vegetation cover formed of rain forest fragments. The climate is tropical (warm and humid), with rainy periods ranging from autumn to winter (March-September), average temperature of $25^{\circ} \mathrm{C}$ and average rainfall of $2000 \mathrm{~mm}$ (IGARASSU, 2000). Climatic information was obtained from the Pernambuco Technology Institute (ITEP).

\section{Collection and identification of phlebotomines}

Specimens were collected on three consecutive nights every month from October 2015 to September 2016, from 5 pm to 5 am, using seven light traps of the Centers for Disease Control (CDC) model, with a mean distance of $900 \mathrm{~m}$ among them. Each trap was installed at a height of $1.5 \mathrm{~m}$ above the ground and in different ecotopes: indoors (P1 and P2), peridomestic areas (P3-stable, P4-kennel and P5-hen house) and forested areas (P6 and P7) (Figure 1). The specimens thus caught were identified in accordance with the dichotomous key of Young \& Duncan

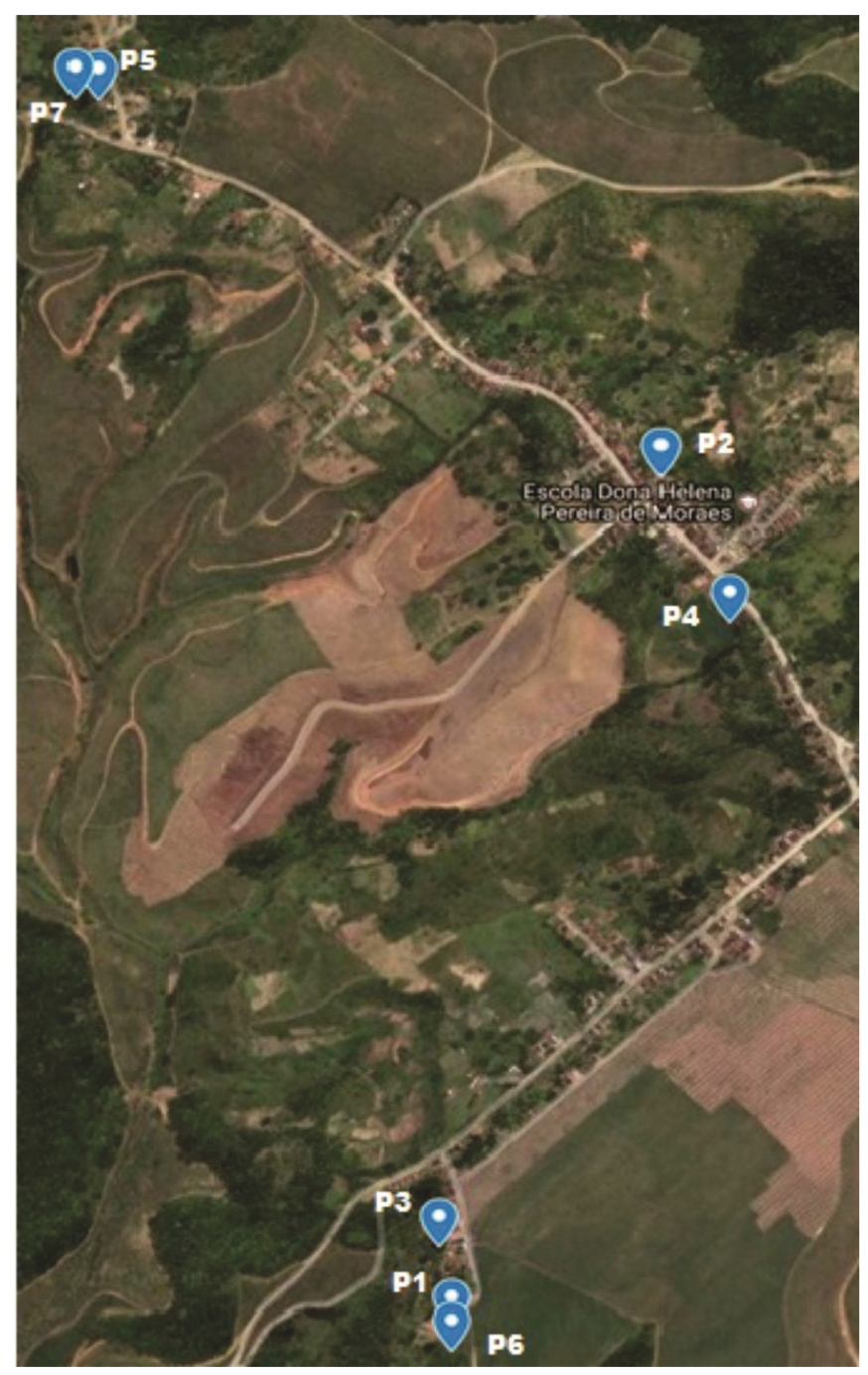

Figure 1. Spatial distribution of collection points in Igarassu, PE, Brazil. 
(1994). The thorax and abdomen of specimens that had been identified as female (except for the three last segments, which had been used for morphological identification) were then conserved in 70\% alcohol for subsequent molecular Leishmania analysis.

\section{DNA extraction and polymerase chain reaction test (PCR)}

DNA was extracted from 490 phlebotomines ( $L$. chot $i=405$; L. whitmani $=73 ;$ L. sordellii $=10 ;$. evandro $i=1$ and $L$. longispina $=1$ ), which were divided into 100 pools containing approximately five specimens each. For DNA extraction, the Purelink ${ }^{\mathrm{TM}}$ Genomic DNA mini-kit (Invitrogen, USA) was used, in accordance with the manufacturer's recommendations. The DNA samples were analyzed by PCR using the primers L1 (5'-GGG GAG GGG CGT TCT GCG AA- 3') and L2 (5'-GGC CCA CTA TAT TAC ACC AAC CCC-3') for the genus Leishmania (MICHALSKY et al., 2002). DNA extracted from blood of dogs infected with Leishmania infantum was used as the positive control, and DNA from animals in non-endemic areas that had been proven to be uninfected was used as the negative control.

\section{Data analysis}

The results were analyzed by descriptive statistics. The Lilliefors test was used to verify the normality of the data. The relationship between the number of phlebotomines collected and the climatic variations was evaluated through the Friedman test. This test was also used to evaluate the presence of males and females in the environment, along with the month variations in the number of species collected. The chi-square $\left(x^{2}\right)$ test with Yates correction was used to compare occurrences of phlebotomine species in different ecotopes. The significance level was taken to be $5 \%$. The BioEstat software, version 5.3, was used to perform the statistical calculations.

\section{Results}

A total of 2,174 phlebotomines were caught, and females predominated $(58.3 \%$; $1,267 / 2,174)$ over males $(41.7 \%$; $907 / 2,174)$. Thus, the sex ratio $(\mathrm{M}: \mathrm{F})$ was $1: 1.40$, but there was no statistical difference $(\mathrm{Fr}=1.3333 ; \mathrm{p}=0.2482)$.

Ten species of phlebotomines were identified. Among them, Lutzomyia choti predominated $(88.2 \% ; 1,917 / 2,174)$, followed by Lutzomyia whitmani $(8.1 \% ; 176 / 2,174)$ and Lutzomyia sordellii $(1.5 \% ; 33 / 2,174)$, which together represented more than $90 \%$ of the specimens collected (Table 1). L. choti, L. whitmani and L. sordellii were also the only species found at all collection points. All collected specimens were deposited in an entomological collection (protocol number: 98/2016) of the Unidade Acadêmica de Garanhuns, Universidade Federal Rural de Pernambuco.

The majority of the phlebotomines were caught in peridomestic areas, which accounted for 1,394 specimens (64.1\%), followed by forest areas with $733(33.7 \%)$ and lastly indoors with 47 (2.2\%) (Table 1). The largest proportion of the specimens of $L$. choti $(824 / 1,917)$ were collected in a peridomestic area (P5), from a hen house next to a tree trunk. The next largest proportion was from a forested area $(481 / 1,917)(\mathrm{P} 3),\left(x^{2}=37,402 ; \mathrm{p}=0.0000\right)$. L. whitmani (108/176) was also most frequently found in a peridomestic area, but in this case it was in a stable (P3). Very few samples of this species were found indoors $(9 / 176)$. L. sordellii (15/33) was collected in a forested area (P6) (Table 1). L. choti predominated at points $\mathrm{P} 3$ and $\mathrm{P} 6$, compared with $L$. whitmani $\left(x^{2}=40,272 ; \mathrm{p}=0.0000\right)$. It is important to highlight that L. complexa, L. longispina and L. wellcomei were found in the peridomestic environment (Table 1).

Phlebotomines were found in all the months of the study, corresponding to a mean of 181 sandflies a month. Nevertheless, the monthly density was higher in January 2015 (395) and May 2016 (802). In May, the temperature was lower than in January, whereas the humidity and rainfall were higher (Figure 2). Surprisingly, climatic variations in temperature $(\mathrm{Fr}=3.0000$;

Table 1. Phlebotomines species collected of Igarassu - Pernambuco, from October 2015 to September 2016, using light traps of the Centers for Disease Control (CDC) model.

\begin{tabular}{|c|c|c|c|c|c|c|c|c|c|}
\hline \multirow{3}{*}{ SPECIES } & \multirow{2}{*}{ MALE } & \multirow{2}{*}{ FEMALE } & \multicolumn{2}{|c|}{ DOMICILE } & \multicolumn{3}{|c|}{ PERIDOMICILE } & \multicolumn{2}{|c|}{ FOREST } \\
\hline & & & P1 & P2 & P3 & P4 & P5 & P6 & P7 \\
\hline & & & & & AF (RF\%) & & & & \\
\hline L. choti & $741(38.7)$ & $1176(61.3)$ & $26(1.3)$ & $4(0.2)$ & $397(20.7)$ & $30(1.6)$ & $824(43)$ & $481(25.1)$ & $155(8.1)$ \\
\hline L. whitmani & $103(58.5)$ & $73(41.5)$ & $7(4.0)$ & $2(1.1)$ & $108(61.4)$ & $2(1.1)$ & $8(4.5)$ & $38(21.6)$ & $11(6.3)$ \\
\hline L. sordellii & $23(69.7)$ & $10(30.3)$ & $2(6.1)$ & $1(3.0)$ & $2(6.1)$ & $2(6.1)$ & $6(18.2)$ & $15(45.5)$ & $5(15.2)$ \\
\hline L. quinquefer & $12(100)$ & 0 & $1(8.3)$ & 0 & 0 & 0 & 0 & $11(91.7)$ & 0 \\
\hline L. wellcomei & $12(100)$ & 0 & 0 & 0 & $5(41.7)$ & 0 & $1(8.3)$ & $4(33.3)$ & $2(16.7)$ \\
\hline L. evandroi & $10(90.9)$ & $1(9.1)$ & $2(18.2)$ & 0 & 0 & 0 & $4(36.4)$ & $3(27.3)$ & $2(18.2)$ \\
\hline L. longispina & $2(66.7)$ & $1(33.3)$ & 0 & 0 & $1(33.3)$ & 0 & $1(33.3)$ & 0 & $1(33.3)$ \\
\hline L. brasiliensis & $2(100)$ & 0 & 0 & $1(50)$ & 0 & 0 & 0 & 0 & $1(50)$ \\
\hline L. complexa & $1(100)$ & 0 & 0 & 0 & 0 & 0 & $1(100)$ & 0 & 0 \\
\hline L. naftalekatzi & $1(100)$ & 0 & 0 & 0 & 0 & 0 & 0 & $1(100)$ & 0 \\
\hline Lutzomyia spp. & 0 & $6(100)$ & $1(16.7)$ & 0 & $2(33.3)$ & 0 & 0 & $2(33.3)$ & $1(16.7)$ \\
\hline Total & $907(41.7)$ & $1267(58.3)$ & $39(1.8)$ & $8(0.4)$ & $515(23.7)$ & $34(1.6)$ & $845(38.9)$ & $555(25.5)$ & $178(8.2)$ \\
\hline
\end{tabular}

AF - Absolute Frequency; RF - Relative Frequency. 


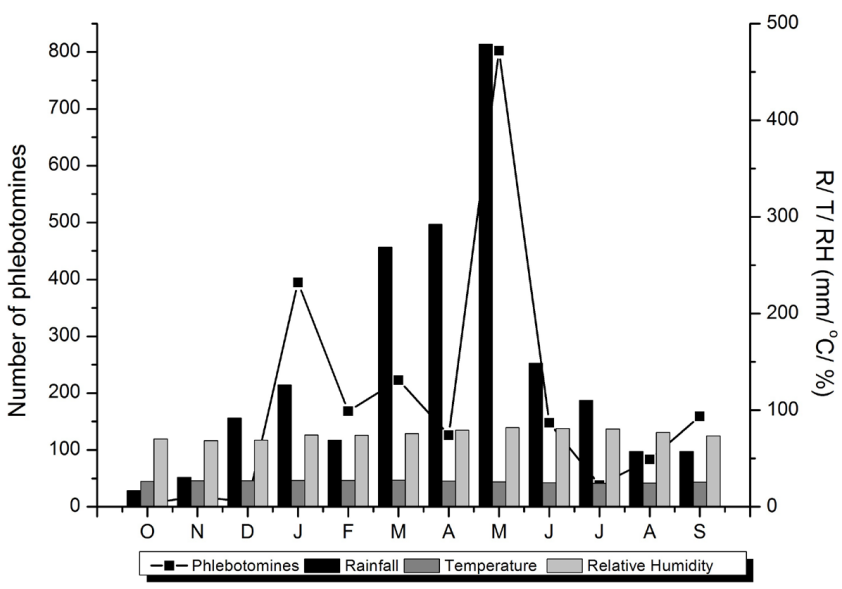

Figure 2. Occurrence of phlebotomines in Igarassu, PE, Brazil and climatic conditions observed in the study from October 2015 to September 2016.

$\mathrm{p}=0.0833)$, relative humidity $(\mathrm{Fr}=1.3333 ; \mathrm{p}=0.2482)$ and rainfall $(\mathrm{Fr}=0.333 ; \mathrm{p}=0.5637)$ were not found to have any influence on the abundance of phlebotomines. In relation to species, L. choti presented peaks in its population density in January 2015 and May 2016, and was the only species caught in all months. L. whitmani was most abundant in May 2016 and was absent only in October and November 2015 (Table 1).

All samples were found Leishmania negative in the molecular analysis.

\section{Discussion}

The phlebotomine fauna was evaluated in a rural area endemic for ACL, located in the northeastern region of Brazil. A wide diversity of species was observed in the present study (L. choti, L. whitmani, L. sordellii, L. quinquefer, L. wellcomei, L. evandroi, L. longispina, L. brasiliensis, L. complexa and L. naftalekatzi). These findings are important regarding the epidemiology of leishmaniasis in the study area, given that an increased number of species was observed in comparison with studies conducted in the 1980s, in which three species were identified: L. whitmani, L. evandroi and L. squamiventris (LUCENA et al., 1984). It is likely that, with the destruction of natural habitats and the dispersion of wild animals that are food sources for sandflies, these dipterans have been undergoing modification of their behavior, such that they have sought new targets on which to feed (i.e. dogs and humans), thus coming closer to peridomestic areas.

Lutzomyia choti was the most frequent species. Although little is known about this species, it has often been observed in areas endemic for ACL (ANDRADE et al., 2005; MIRANDA et al., 2015). Therefore, its role in transmission of protozoa belonging to the genus Leishmania deserves to be better investigated.

The species L. choti, L. sordellii and L. whitmani were collected in all the environments studied. This demonstrated the capacity of these species to adapt to houses, especially those located next to rain forest fragments. The location with the highest number of specimens caught was the peridomestic area, and this finding corroborates previous studies (BARATA et al., 2005; SILVA et al., 2010). It is important to highlight that in the present study, animal shelters (hen houses, stables and a piggery) were found in peridomestic areas, and their presence may have influenced the number of specimens collected.

It is known that climatic and other factors (such as the presence of vegetation) have an influence on the incidence of phlebotomines (COSTA et al., 2013). In addition, some species may present different seasonal patterns in the same geographic area, due to climatic variations (GUIMARÁES et al., 2012). In the present study, the month with the highest numbers of specimens and species collected was the month with the highest relative humidity and rainfall. These factors favor growth of vegetation and accumulation of organic matter in the soil, thus making it possible for breeding sites to appear (DIAS et al., 2007). Although representative correlations between sandfly numbers and rainfall and relative humidity have been reported (GUIMARÁES et al., 2012), climatic variation did not have any influence on the abundance of specimens in the present study.

All the specimens molecularly analyzed were negative for Leishmania. It is likely that the lower number of specimens analyzed did not allow detection of Leishmania spp. DNA. Therefore, studies with larger numbers of samples should be performed in order to elucidate the possible roles of species that were proven to transmit ACL in the present study area or were suspected of this.

The present study contributed towards knowledge of the phlebotomine fauna in an area endemic for ACL in the state of Pernambuco. The abundant presence of $L$. choti reveals the importance of further studies to evaluate its role as a possible vector. In addition, the presence of $L$. whitmani makes it possible for outbreaks to occur. Lastly, the rainy period was considered to be the time of highest risk in the study area, given the greater presence of phlebotomines.

\section{References}

Agra MCR, Costa PL, Duque AES, Soares ENL, Alves LC, Ramos RAN, et al. Sandflies (Diptera: Psychodidae) in an urban area of Northeastern Brazil. Rev Soc Bras Med Trop 2016; 49(6): 698-702. PMid:28001216. http:// dx.doi.org/10.1590/0037-8682-0147-2016.

Andrade MS, Valença HF, Silva AL, Almeida FA, Almeida EL, Brito MEF, et al. Sandfly fauna in a military training area endemic for american tegumentary leishmaniasis in the atlantic rain forest region of Pernambuco, Brazil. Cad Saude Publica 2005; 21(6): 1761-1767. PMid:16410860. http://dx.doi.org/10.1590/S0102-311X2005000600023.

Balbino VQ, Andrade MS, Coutinho-Abreu I, Sonoda IV, Marcondes CB, Shaw JJ, et al. Sand flies (Diptera: Psychodidae) in Pernambuco State, northeastern Brazil: The presence of species incriminated as vectors of cutaneous leishmaniasis in the Amazon region. Zootaxa 2005; 1078(1): 25-32. http://dx.doi.org/10.11646/zootaxa.1078.1.2.

Barata RA, França-Silva JC, Mayrink W, Silva JC, Prata A, Lorora ES, et al. Aspectos da ecologia e do comportamento de flebotomíneos em área endêmica de leishmaniose visceral, Minas Gerais. Rev Soc Bras Med Trop 2005; 38(3): 421-425. PMid:16172760. http://dx.doi.org/10.1590/ S0037-86822005000500012.

Brandão-Filho SP, Brito MEF, Martins CAP, Sommer IB, Valença HF, Almeida FA, et al. Leishmaniose tegumentar americana em centro de 
treinamento militar localizado na Zona da Mata de Pernambuco, Brasil. Rev Soc Bras Med Trop 1998; 31(6): 575-578. PMid:9859704. http:// dx.doi.org/10.1590/S0037-86821998000600012.

Costa PL, Dantas-Torres F, Silva FJ, Guimarães VC, Gaudêncio K, Brandão-Filho SP. Ecology of Lutzomyia longipalpis in an area of visceral leishmaniasis transmission in north-eastern Brazil. Acta Trop 2013; 126(2): 99-102. PMid:23369878. http://dx.doi.org/10.1016/j. actatropica.2013.01.011

Costa SM, Cechinei M, Bandeira V, Zannuncio JC, Lainson R, Rangel WF. Lutzomyia (Nyssomyia) whitmani s. I. (Antunes \& Coutinho, 1939) (Diptera: Psychodidae: Phlebotominae): geographical distribution and the epidemiology of American cutaneous leishmanisais in Brazil - minireview. Mem Inst Oswaldo Cruz 2007; 102(2): 149-153. PMid:17426877. http://dx.doi.org/10.1590/S0074-02762007005000016.

Dantas-Torres F, Andrade AJ, Tenório KER, Andrade JD Fo, Balbino VQ, Brandão-Filho SP. Phlebotomine sand flies (Diptera: Psychodidae: Phlebotominae) in the State of Pernambuco. Rev Soc Bras Med Trop 2010; 43(6): 733-736. PMid:21181035. http://dx.doi.org/10.1590/ S0037-86822010000600028.

Dias ES, França-Silva JC, Silva JC, Monteiro EM, Paula KM, Gonçalves $\mathrm{CM}$, et al. Flebotomíneos (Diptera: Psychodidae) de um foco de leishmaniose tegumentar no Estado de Minas Gerais. Rev Soc Bras Med Trop 2007; 40(1): 49-52. PMid:17486253. http://dx.doi.org/10.1590/ S0037-86822007000100009.

Guimarães VCFV, Costa PL, Silva FJ, Silva KT, Silva KG, Araújo AIF, et al. Phlebotomine sandflies (Diptera: Psychodidae) in São Vicente Férrer, a sympatric area to cutaneous and visceral leishmaniasis in the state of Pernambuco, Brazil. Rev Soc Bras Med Trop 2012; 45(1): 66-70. PMid:22370831. http://dx.doi.org/10.1590/S0037-86822012000100013.

Igarassu. Prefeitura Municipal. Secretaria de Planejamento, Meio Ambiente e Patrimônio Histórico. Banco de dados de Igarassu. Igarassu: Prefeitura Municipal; 2000.

Killick-Kendrick R. The biology and control of phlebotomine sand flies. Clin Dermatol 1999; 17(3): 279-289. PMid:10384867. http://dx.doi. org/10.1016/S0738-081X(99)00046-2.

Kovats RS, Lendrum DHC, McMichael AJ, Woodward A, Cox JS. Early effects of climate change: do they include changes in vector-borne disease? Philos Trans R Soc Lond B Biol Sci 2001; 356(1411): 1057-1068. PMid:11516383. http://dx.doi.org/10.1098/rstb.2001.0894.
Lucena DT, Oliveira MHCC, Leal MC. Variação mensal dos flebotomíneos (Diptera-Psychodidae) de Igarassu, PE. Cad Ômega Série Biol 1984; 1(1): $19-27$

Maroli M, Feliciangeli MD, Bichaud L, Charrel RN, Gradoni L. Phlebotomine sandflies and the spreading of leishmaniases and other diseases of public health concern. Med Vet Entomol 2013; 27(2): 123-147. PMid:22924419. http://dx.doi.org/10.1111/j.1365-2915.2012.01034.x.

Michalsky EM, Fortes-Dias CL, Pimenta PFP, Secundino NFC, Dias ES. Assessment of PCR in the detection of Leishmania spp in experimentally infected individual phlebotomine sandflies (Diptera: Psychodidae: Phlebotominae). Rev Inst Med Trop Sao Paulo 2002; 44(5): 255-259. PMid:12436164. http://dx.doi.org/10.1590/S0036-46652002000500004.

Miranda DEO, Sales KGS, Faustino MAG, Alves LC, Brandão-Filho SP, Dantas-Torres F, et al. Ecology of sand flies in a low-density residential rural area with mixed forest/agricultural exploitation, in north-eastern Brazil. Acta Trop 2015; 146: 89-94. PMid:25792416. http://dx.doi. org/10.1016/j.actatropica.2015.03.011

Patz JA, Daszak P, Tabor GM, Aguirre AA, Pearl M, Epstein J, et al. Unhealthy landscape: policy recommendations on land use change and infectious disease emergence. Environ Health Perspect 2004; 112(10): 1092-1098. PMid:15238283. http://dx.doi.org/10.1289/ehp.6877.

Ramos JVA. Avaliação dos aspectos epidemiológicos da leishmaniose (na população humana e animal) no distrito de Três Ladeiras, município de Igarassu, PE [Tese]. Pernambuco: Universidade Federal Rural de Pernambuco; 2015.

Shimabukuro PHF, Galati EAB. Lista de espécies de Phlebotominae (Diptera, Psychodidae) do estado de São Paulo, Brasil, com comentários sobre sua distribuição geográfica. Biot Neotrop 2011; 11(1a): 1-20.

Silva DF, Vasconcelos SD. Phlebotomine sandflies in fragments of rain forest in Recife, Pernambuco State. Rev Soc Bras Med Trop 2005; 38(3): 264-266. PMid:15895182. http://dx.doi.org/10.1590/S003786822005000300013

Silva FS, Carvalho LPC, Cardoso FP, Moraes JLP, Rebêlo JMM. Sand flies (Diptera: Psychodidae) in a Cerrado area of the Maranhão State, Brazil. Neotrop Entomol 2010; 39(6): 1032-1038. PMid:21271075. http://dx.doi.org/10.1590/S1519-566X2010000600028.

Young DG, Duncan MA. Guide to the identification and geographic distribution of Lutzomyia sand flies in Mexico, the west Indies, Central and South America (Diptera: Psychodidae). Gainesville: Associated Publishers, American Entomological Institute; 1994. no. 54, Memoirs of the American Entomological Institute. 